Jurnal Pembangunan Pendidikan: Fondasi dan Aplikasi

Volume 3, No 2, Desember 2015 (142-150)

Tersedia Online: http://journal.uny.ac.id/index.php/jppfa

\title{
PENDIDIKAN NILAI KEBANGSAAN MELALUI BUDAYA SEKOLAH DI SMA TARUNA NUSANTARA DAN SMA KOLESE DE BRITTO \\ ${ }^{1)}$ Emmanuel Kus Eddy Sartono, ${ }^{2)}$ Noeng Muhadjir, ${ }^{3)}$ Sumarno \\ ${ }^{1,2,3)}$ Universitas Negeri Yogyakarta \\ 1)pjj_kuseddysartono@yahoo.com
}

\begin{abstract}
Abstrak
Penelitian ini bertujuan untuk menemukan pola pendidikan nilai kebangsaan sebagai hasil sintesis dari pola pendidikan nilai kebangsaan melalui budaya sekolah di SMA Taruna Nusantara dan SMA Kolese De Britto. Jenis penelitian ini adalah penelitian kualitatif-fenomenologi. Subjek penelitian adalah pengurus yayasan, kepala sekolah, wakil kepala sekolah, guru, siswa, karyawan, dan orang tua. Data dikumpulkan melalui wawancara mendalam, observasi, dan dokumentasi. Teknik analisis data menggunakan model analisis interaktif, meliputi: reduksi data, penyajian data dan kesimpulan. Hasil penelitian menunjukkan bahwa ada perbedaan dan persamaan pola pendidikan nilai-nilai kebangsaan melalui budaya sekolah antara SMA Taruna Nusantara dengan SMA Kolese De Britto, meskipun demikian penelitian ini menemukan budaya sekolah efektif untuk membentuk karakter kebangsaan siswa. Sintesisnya adalah penggabungan Sistem Among, cara Tutwuri Handayani, budaya kedisiplinan, Paradigma Pedagogi Ignasian, cura personalis, dan budaya pendidikan bebas akan meningkatkan penanaman nilai kebangsaan siswa tidak sekedar pada ranah kognitif dan afektif, tetapi sampai pada ranah perilaku kebangsaan.
\end{abstract}

Kata kunci: pendidikan nilai kebangsaan, budaya sekolah

\section{NATIONALISM VALUE EDUCATION THROUGH THE SCHOOL CULTURE IN SMA TARUNA NUSANTARA AND SMA KOLESE DE BRITTO \\ ${ }^{1)}$ Emmanuel Kus Eddy Sartono, ${ }^{2)}$ Noeng Muhadjir, ${ }^{3)}$ Sumarno \\ ${ }^{1,2,3)}$ Universitas Negeri Yogyakarta \\ 1)pjj_kuseddysartono@yahoo.com}

\begin{abstract}
This study aims to find patterns of national values education synthesis results of pattern national values through cultural education in SMA Taruna Nusantara and SMA Kolese De Britto. The research is a qualitative research-phenomenology. Subjects were board of trustees, principals, vice-principals, teachers, students, employees and parents. Data were collected through interviews, observation, and documentation. Analysis using interactive model, include: data reduction, data presentation and conclusion. The results showed that there are differences and similarities of pattern national values education through school culture between the SMA Taruna Nusantara Colleges De Britto, however this study found an effective school culture to shape the national character of students. Among the incorporation synthesis system, how Tutwuri Hand, disciplinary culture, Ignatian Pedagogical Paradigm, cura personalist free education and culture will increase the cultivation of students' national values not only on the cognitive and affective behavior but to the realm of nationality.
\end{abstract}

Keywords: nationalism value education, school culture 


\section{PENDAHULUAN}

Menurut Sastrapratedja (2001, pp.1617) wawasan kebangsaan Indonesia dewasa ini dihadapkan pada tiga tantangan besar. Tantangan pertama adalah tantangan internal yaitu permasalahan-permasalahan nasional yang membuat ikatan kebangsaan menjadi rapuh. Tantangan kedua adalah masalah keraguan terhadap Pancasila sebagai jati diri atau identitas diri bangsa. Sebagian masyarakat cenderung mengambil identitas kelompok (etnis, bahasa daerah, budaya, agama, suku) sebagai referensi identitas bangsa. Tantangan ketiga globalisasi. Globalisasi mengakibatkan homogenisasi budaya sehingga dapat mencairkan ikatan budaya nasional. Namun, pada saat yang sama sebagai reaksi terhadap homogenisasi, muncul gerakan yang menekankan unsur-unsur lokal, sehingga dapat terjadi bahwa perbedaan etnis atau agama menjadi tajam.

Menghadapi tantangan kebangsaan tersebut, posisi pendidikan nilai kebangsaan terasa menjadi sangat urgen untuk ditingkatkan. Hal ini sejalan dengan pendapat Gellner (2008, p.34) bahwa kebangsaan sebenarnya tidak mempunyai akar begitu kuat dalam kejiwaan manusia. Kebangsaan harus diciptakan dan ditumbuhkan. Mencermati lembaran kurikulum pendidikan nasional dari masa ke masa, ditemukan fakta bahwa sudah ada upaya berkesinambungan untuk menanamkan nilai kebangsaan. Namun, pelaksanaan pendidikan nilai kebangsaan sebelum keluarnya Kurikulum 2013 lebih menekankan strategi penyajian dimensi kognitif (Zuchdi, 2010, p.40). Hasilnya yang terbangun adalah kebangsaan simbolik atau kebangsaan semu dan gagal membangun kebangsaan sejati.

Ada beberapa strategi yang dapat diterapkan dalam pelaksanaan integrasi pendidikan nilai dalam proses pendidikan, yaitu melalui kurikulum, pembelajaran, kepemimpinan, kegiatan kesiswaan, maupun budaya sekolah. Menurut Wagiran (2011, p.2) mengintegrasikan pendidikan nilai dalam budaya sekolah merupakan upaya paling efektif, mengingat penanaman nilai-nilai yang bersifat afektif akan lebih mudah melalui keteladanan dan pembiasaan dalam kehidupan sehari-hari. Oleh karena itu, diperlukan pemahaman dan langkah komprehensif untuk menciptakan budaya sekolah bagi tumbuh dan berkembang- nya nilai-nilai yang akan mewarnai kehidupan dan jati diri warga sekolah.

Hal tersebut sejalan dengan pemikiran Sastraprateja (2001, p.1) bahwa pendekatan budaya untuk meningkatkan kinerja sekolah akan lebih efektif jika dibandingkan dengan pendekatan struktural. Pendekatan budaya dengan fokus pada budaya keunggulan dengan menekankan pengubahan pada pikiran, kata-kata, sikap, perbuatan, dan hati setiap warga sekolah. Pendidikan nilai yang dilakukan secara formal hampir pasti tidak akan mengenai sasaran, karena disposisi murid tidak terbangun dengan baik, sehingga batinnya tidak terbuka dan tidak siap untuk menerima nilai-nilai yang ditawarkan. Pendidikan nilai kebangsaan merupakan komponen dari pendidikan politik. Sekolah merupakan salah satu agen utama pendidikan politik. Niemi Hepburn sebagaimana dikutip oleh Prough (2008, pp.4-5) menyatakan bahwa : "individuals probably experience more change in their political view between the ages of fourteen and twenty-five than at any other point their lives". Seseorang mungkin akan mengalami perubahan pandangan politik lebih banyak antara usia 14-25 tahun dari pada usia-usia lain dalam kehidupannya. Masa Sekolah Menengah Atas termasuk dalam usia itu. Oleh karena itu, Sekolah Menengah Atas merupakan jenjang yang menarik untuk diteliti proses pendidik nilai kebangsaannya.

Bertolak dari berbagai alasan di atas, peneliti tertarik untuk melakukan penelitian tentang: Pendidikan Nilai Kebangsaan melalui Budaya Sekolah (Studi Fenomenologi Di SMA Taruna Nusantara Magelang dan SMA Kolese De Britto Yogyakarta). Ketertarikan peneliti pada dua SMA tersebut didasarkan adanya keunikan budaya di sekolah tersebut yang tidak ditemukan di sekolah yang lain.

Tujuan penelitian ini untuk membuat deskripsi berbobot pola pendidikan nilai kebangsaan melalui budaya sekolah di SMA Taruna Nusantara dan SMA Kolese De Britto, serta membandingkannya untuk memperoleh pola pendidikan nilai kebangsaan hasil sintesis dari pola pendidikan nilai kebangsaan melalui budaya sekolah di SMA Taruna $\mathrm{Nu}$ santara dan SMA Kolese De Britto. Dengan harapan hasilnya secara teoretis dapat memberikan manfaat bagi perkembangan ilmu pendidikan, dan secara praktis memberikan kontribusi alternatif pelaksanaan pendidikan 
nilai kebangsaan yang tepat bagi bangsa Indonesia.

\section{METODE PENELITIAN}

Jenis penelitian ini adalah penelitian kualitatif dengan pendekatan fenomenologi. Pendekatan fenomenologi menjadi pilihan dengan pertimbangan penelitian ini berupaya untuk mengungkap fenomena pendidikan nilai kebangsaan melalui budaya sekolah. Penelitian ini secara khusus menekankan pada pengembangan makna dan mendapatkan pandangan yang mengalami dan mendalami fenomena tersebut. Penelitian ini mengamati fenomena-fenomena konseptual subjek yang diamati melalui tindakan dan pemikirannya guna memahami makna yang disusun oleh subjek di sekitar kejadian sehari-hari.

Penelitian ini dilaksanakan di SMA Trauna Nusantara Magelang dan SMA Kolese De Britto Yogyakarta. Pemilihan kedua sekolah tersebut secara purposif, karena kedua sekolah memiliki budaya sekolah unik yang mendukung pelaksanaan pendidikan nilai kebangsaan. Penelitian dilaksanakan selama 12 (dua belas) bulan, dari awal Januari 2013 sampai dengan akhir Desember 2013.

Mengingat budaya sekolah adalah sebuah kesatuan dari warga sekolah dan masyarakat, maka dalam penelitian ini yang menjadi subjek penelitian adalah pengurus yayasan, kepala sekolah, wakil kepala sekolah, guru, karyawan, siswa dan orang tua siswa. Objek penelitian ini adalah situasi sosial di sekolah yang terdiri dari tiga unsur yaitu: tempat atau ruang-ruang yang ada di sekolah, warga sekolah sebagai pelaku, serta aktivitas yang dilakukan oleh warga sekolah yang berkaitan dengan pola pendidikan nilai kebangsaan melalui budaya sekolah.

Teknik pengumpulan datanya lebih banyak pada observasi berperan serta (participan observation), wawancara mendalam (in depth interview) dan dokumentasi (document review). Dalam penelitian ini yang menjadi instrumen penelitian adalah peneliti sendiri. Peneliti sebagai instrumen penelitian melaksanakan fungsi menetapkan fokus penelitian, memilih informan sebagai sumber data, melakukan pengumpulan data, menilai kualitas data, analisis data, menafsirkan data, dan membuat kesimpulan atas temuannya.
Untuk mendukung keabsahan data penelitian ini, dilakukan dengan uji kredibilitas data dengan cara memperpanjang masa pengamatan, meningkatkan ketekunan dengan melakukan pengamatan yang terusmenerus, triangulasi (teknik, sumber dan waktu), serta Peer debriefing (membicarakannya dengan orang lain) yaitu mengekspos hasil sementara atau hasil akhir yang diperoleh dalam bentuk diskusi analitik dengan rekanrekan sejawat.

Teknik analisis data menggunakan model analisis interaktif (Miles \& Huberman, 1992, p.20). Aktivitas dalam analisis data tersebut, meliputi: data reduction, data display, dan conclusion drawing/verification. Melalui upaya tersebut diharapkan dapat memperoleh jawaban atas permaslahan dalam penelitian ini.

\section{HASIL PENELITIAN DAN PEMBAHASAN}

\section{Kurikulum Sekolah Mendukung Pendidikan Nilai Kebangsaan}

Konsep teori dan filosofi mengenai kurikulum yang dianut SMA Kolese De Britto ada kesamaan dengan SMA Taruna Nusantara adalah kurikulum dalam arti luas, yakni segala sesuatu yang berpengaruh terhadap proses pendidikan untuk mencapai kedewasaan anak didik. Kurikulum SMA Taruna Nusantara meliputi perangkat lunak silabus dan sistem pendidikan, sumber daya manusia, serta perangkat keras dan lingkungan. Perangkat lunak kurikulum SMA Taruna nusantara terdiri atas dua, Kurikulum Nasional yang ditetapkan oleh Departemen Pendidikan Nasional dan Kurikulum Khusus SMA Taruna Nusantara.

SMA Kolese De Britto Tahun Ajaran 2012/2013 mengacu pada Kurikulum Tingkat Satuan Pendidikan terdiri dari tiga komponen yaitu: mata pelajaran, muatan lokal dan pengembangan diri. Muatan lokal spiritualitas Ignasian dipilih sebagai kegiatan intrakurikuler berdasarkan semangat dasar sekaligus ciri khas SMA Kolese De Britto. Hal ini diambil berdasar uraian dalam Permendiknas No. 53 Tahun 2006 tentang Pengembangan Diri yang menyatakan bahwa substansi muatan lokal ditentukan oleh satuan pendidikan. Sesuai dengan esensi penjelasan Permendiknas No. 53 Tahun 2006 tentang Pengembangan Diri, kegiatan pendampingan yang dilak- 
sanakan di luar jam pelajaran merupakan bagian dari pelaksanaan kurikulum pengembangan diri.

SMA Taruna Nusantara, di samping Kurikulum Nasional, juga mempunyai Kurikulum Khusus sebagai ciri khas Perguruan Taman Taruna Nusantara, yang membedakan SMA Taruna Nusantara dengan sekolah sederajat di Indonesia. Kurikulum khusus ditujukan untuk mewujudkan visi dan misi SMA Taruna Nusantara. Mengacu pada Permendiknas No. 53 Tahun 2006 tentang Pengembangan Diri, kurikulum khusus di SMA Taruna Nusantara merupakan kegiatan pendampingan yang dilaksanakan di luar jam pelajaran dan merupakan bagian dari pelaksanaan kurikulum pengembangan diri.

Kurikulum Khusus SMA Taruna Nusantara merupakan seperangkat mata pelajaran dan mata kegiatan, yang bertujuan untuk menumbuhkembangkan potensi kepemimpinan siswa, sebagai salah satu upaya mencapai visi dan misi seperti yang telah digariskan oleh LPTTN. Isi kurikulum khusus adalah nilainilai luhur bangsa yang perlu ditanamkan pada peserta didik dalam kehidupan seharihari melalui serangkaian kegiatan. Mata Pelajaran Kurikulum Khusus merupakan serangkaian bahan ajaran yang berisi nilainilai luhur bangsa atau nilai-nilai moral yang perlu ditanamkan dalam diri siswa. Nilai-nilai yang perlu diinternalisasikan pada siswa diwujudkan dalam mata pelajaran Kenusantaraan, Bela Negara, Kepemimpinan, yang didukung kelompok mata pelajaran sosial humaniora dari Kurikulum Nasional. Nilai-nilai moral yang disampaikan melalui mata pelajaran tersebut diaktualisasikan dalam kehidupan sehari-hari melalui berbagai kegiatan. Berdasarkan karakteristik jenis kegiatan dapat diorganisasi dalam kegiatan rutin terjadwal, kegiatan terprogram, kegiatan terproyek, kegiatan kreatif mandiri.

\section{Kegiatan Mendukung Pendidikan Nilai Kebangsaan}

Ada kesamaan konsep tentang pengelompokan jenis kegiatan SMA Taruna Nusantara dengan SMA Kolese De Britto. Berdasarkan tingkatan, di SMA Taruna Nusantara, meliputi: tahap penanaman dan penumbuhan (kelas X), tahap pengembangan (kelas XI), dan tahap pemantapan (kelas XII). Ber- dasarkan tingkatan di SMA Kolese De Britto mengelompokkan kegiatan pendampingan siswa di SMA Kolese De Britto di setiap tingkat dengan orientasi yang sama dengan SMA Taruna Nusantara hanya istilah orientasinya saja yang berbeda. Siswa kelas X lebih diarahkan pada proses pengenalan dan pembiasaan, siswa kelas XI lebih diarahkan pada proses sosialisasi, dan siswa kelas XII diarahkan pada proses internalisasi nilai-nilai.

Untuk membantu siswa kelas X memasuki dan menyesuaikan diri dengan jenjang pendidikan yang baru, SMA Taruna Nusantara menyelenggarakan kegiatan Pendidikan Dasar Kedisiplinan dan Kepemimpinan (PDK). Tujuan diselenggarakannya PDK adalah untuk menanamkan dan menumbuhkembangkan potensi kepemimpinan siswa yang beriman dan bertaqwa kepada Tuhan Yang Maha Esa, berdisiplin tinggi, berprestasi, berwawasan kebangsaan, kejuangan dan kebudayaan.

Kegiatan PDK memuat sub-sub kegiatan yaitu Upacara pembukaan PDK, Masa Orientasi Siswa (MOS), Perkemahan Sabtu Minggu (Persami), Upacara Puncak Tidar, Ziarah ke Taman Makan Pahlawan, Napak Tilas Rute Panglima Besar Sudirman (RPS), Pilih Kesatria Tangkas (PKT), dan Upacara Penutupan PDK. Kegiatannya beorientasi pada penanaman wawasan kebangsaan dan wawasan kejuangan.

Sedang di SMA Kolese De Britto Proses pengenalan dimulai dari masa orientasi (inisiasi). Dalam inisiasi inilah siswa mulai dikenalkan kultur sekolah, profil siswa, kebiasaan-kebiasaan, dan nilai-nilai yang ditawarkan di sekolah. Pada tingkat ini siswa lebih diajak untuk membangun keakraban (dengan malam keakraban kelas) yang terprogram, studi ekskursi pada jeda semester I ke semester II, forum olah pikir, penyuluhan hukum, narkotika, teknologi, dsb.

Tahap pengembangan dilaksanakan pada siswa kelas XI. Konsep nilai-nilai moral yang sudah ditanamkan pada diri siswa pada saat mengikuti kegiatan kelas $\mathrm{X}$ dikembangkan, di SMA Taruna Nusantara dilakukan melalui kegiatan-kegitan yang konkrit. Siswa diberi kepercayaan untuk melakukan sesuatu dalam bentuk diskusi, main peran, simulasi, dan sebagainya, dengan materi tentang etika dan etiket yang membahas tentang nilai-nilai moral dan kebangsaan dalam kehidupan 
masyarakat, mereka diminta memerankan, sekaligus siswa dapat menginternalisasikan nilai-nilai tersebut kedalam dirinya. Dengan demikian, konsep diri siswa akan terbentuk sesuai dengan potensi masing-masing. Kegiatan menonjol dalam masa pengembangan yang erat berkaitan dengan pendidikan nilai kebangsaan adalah Latihan Hulubalang. Sedang di SMA Kolese De Britto proses pengembangan atau sosialisasi siswa dilakukan melalui kegiatan saling menghargai antarsiswa berbeda jurusan, live-in sosial, bakti sosial, dan kesempatan menyusun karya ilmiah untuk memberi bekal penalaran adalah fokus pada pembinaan siswa kelas XI.

Masa Pemantapan di SMA Taruna Nusantara dengan cara siswa diberi kesempatan untuk mengaktualisasikan dirinya dalam bentuk kegiatan nyata di lapangan bersama teman-temannya dan anggota masyarakat. Siswa didorong untuk berpartisipasi aktif dalam kegiatan tersebut, siswa diberi tanggung jawab untuk menyelesaikan suatu pekerjaan, disini akan terlihat bagaimana ia memenuhi tanggung jawabnya, dalam bersikap, bertindak, berbicara, bertingkah-laku, sebagai orang yang bermoral, beretika, berwawasan kebangsaan, kejuangan dan kebudayaan, seperti yang diharapkan oleh masyarakat. Salah satunya melalui kegiatan Latihan Kemasyarakatan Peduli Lingkungan (LKPL).

Masa pemantapan di SMA Kolese De Britto disebut proses internalisasi dimaksudkan agar siswa dapat membuat simpul-simpul refleksi dari pengalaman selama 3 atau 4 tahun bersekolah di SMA Kolese De Britto. Kegiatan yang merangkum hal ini adalah retret dan geladi rohani. Sebelum siswa lulus, perlu aktivitas yang dapat digunakan untuk merefleksikan perjalan studi sekaligus merencanakan studi lanjut. Untuk itulah SMA
Kolese De Britto selalu diselenggarakan acara education fair, konsultasi psikologi, konsultasi jurusan, sharing tentang karier dan profesi, dan sebagainya.

Dari kegiatan yang dilakukan berdasarkan tingkatan di atas jika dikaitkan dengan pendidikan nilai-nilai kebangsaan, nampak ada perbedaan orientasi antara SMA Taruna Nusantara dengan SMA Kolese de Britto. Di SMA Taruna Nusantara kegiatan dari proses penanaman, pengembangan dan pemantapan ditekankan pada usaha untuk membangun kesadaran rela berkorban serta semangat kejuangan untuk mewujudkan persatuan dan kesatuan bangsa. Sedangkan kegiatan di SMA Kolese De Britto lebih berorientasi pada kesadaran batinnya untuk berbela rasa, kepedulian terhadap keprihatinan masyarakat, bangsa, dan negaranya.

\section{Pendidikan Kebebasan Bertanggungjawab SMA Kolese De Britto}

Pendidikan bebas di SMA Kolese De Britto adalah pendidikan bebas yang bertanggung jawab. Tanggung jawab tidak sekedar pada menanggung konsekuensinya, tetapi bertanggung jawab pada saat pengambilan keputusan bebas yang didasari hirarki nilainilai, norma-norma dan suara hati. Siswa yang dengan tepat mengartikan dan menggunakan kebebasan yang bertanggung jawab, akan terlepas dari paradigma ketahuan-tidak ketahuan. Paradigma ketahuan-tidak ketahuan akan mengambil keputusan berdasarkan apakah orang lain mengetahui tindakannya atau tidak. Jika tidak diketahui orang lain, maka segala sesuatu boleh dilakukan. Sebaliknya jika ada orang lain di sekitarnya, ia akan mengambil keputusan yang lain.

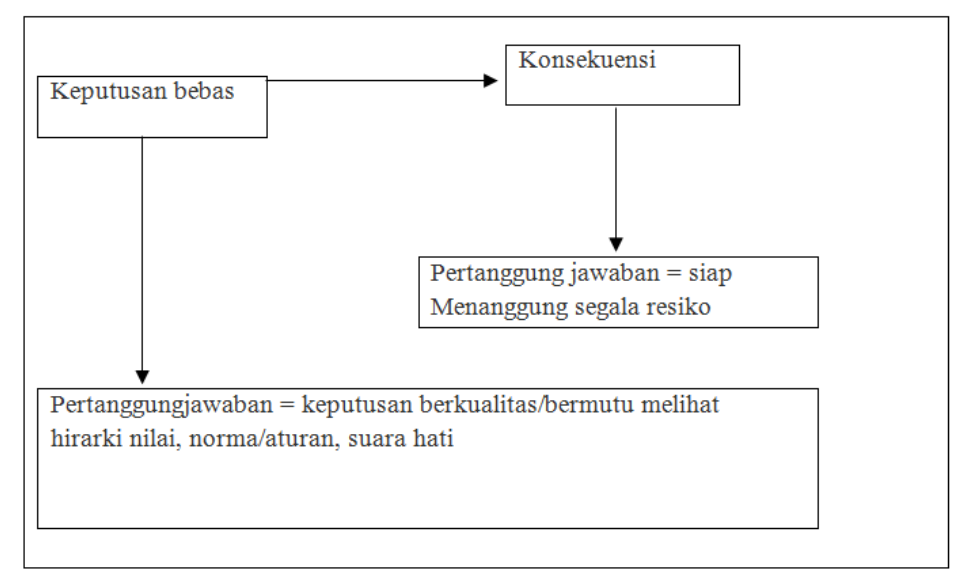


Implementasi kebebasan di SMA Kolese De Britto agar terlaksana dengan sempurna, pertama-tama berarti memberikan bekal pada siswa tentang hirarki nilai-nilai, norma-norma dan pengasahan suara hati. Dengan bekal itu semua, seorang siswa diharapkan mampu membuat keputusan bebas yang berkualitas yang akan dipertanggungjawabkan. Mengajarkan semua itu kepada siswa berarti memberikan pondasi nilai bagi siswa. Penanaman pondasi nilai semacam itu tentunya tidak hanya cukup di ranah kognitif, melainkan juga harus sampai kedalaman hati, yang pada gilirannya harus menjadi konkret dalam tingkah laku dan aktivitas sehari-hari. Untuk penanaman nilai-nilai termasuk nilainilai kebangsaan, SMA Kolese De Britto menerapkan metode "cura personalis" dan "Paradigma Pedagogik Ignasian".

Inti dari Paradigma Pedagogi Ignasian adalah interaksi terus menerus dari tiga poros kegiatan, yakni "pengalaman, refleksi, dan aksi". Ketiga anasir ini dilengkapi dengan pemahaman mengenai konteks tempat pengalaman itu berlangsung serta kegiatan evaluasi setelah selesai setiap aksi. Hal ini terlihat pada Gambar 1.

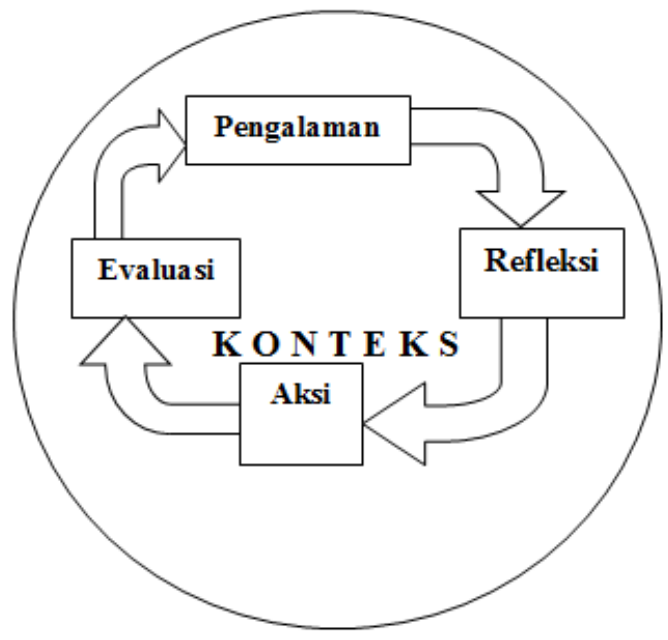

Gambar 1. Pemahaman Konteks

Selain Paradigma Pedagogi Ignasian, ciri pendidikan Yesuit sebagai implementasi dari spiritualitas Ignasian adalah "Cura personalis". Pengertian cura personalis adalah sikap hormat dan penuh penghargaan bagi setiap pribadi manusia dan mengakui kebaikan serta keluhuran martabatnya. Cura personalis adalah kepedulian akan setiap pribadi, memandang setiap orang sebagai insan yang dikenal, dipanggil dan dicintai secara pribadi oleh Allah sendiri. Rumusan tersebut menggarisbawahi arah dasar semangat cura personalis tentang pentingnya guru mengenal dengan baik secara pribadi siswanya dalam suatu relasi interpersonal yang sehat. Tujuannya supaya siswa merasa diterima dan dicintai apa adanya, sehingga tidak perlu terjebak terlalu lama dalam kubangan perasaan diri yang serba gamang dan amburadul.

Melalui budaya pendidikan bebas, pendekatan cura personalis dan penerapan Paradigma Pedagogi Ignasian, nilai penghargaan akan keberagaman sebagai salah satu pilar persatuan dan kesatuan bangsa, tertanam nyata dalam diri siswa. Pendidikan Kolese De Britto dilaksanakan dalam suatu komunitas yang terdiri atas beraneka ragam suku, budaya, agama, dan latar belakang sosial-ekonomi. Dalam komunitas inilah para siswa dibantu untuk berkembang menjadi manusia dewasa yang terbuka dan menghargai keanekaragaman sebagai bagian dari persiapannya untuk kelak menjadi pemimpin yang melayani masyarakat.

Salah satu perkara klasik dalam masyarakat Indonesia pada umumnya adalah pertentangan antara suku bangsa Cina dan Jawa/pribumi. Di SMA Kolese De Britto peneliti melihat betapa keberadaan siswa bersu$\mathrm{ku}$ bangsa Cina dan pribumi bisa membaur tanpa harus berselisih paham hanya karena perbedaan suku bangsa. Uniknya lagi, tidak adanya perselisihan bukan berarti karena menyembunyikan bibit persoalan dalam hati atau pura-pura tak menganggap ada. Namun justru sebaliknya, siswa mengekspresikan perbedaan itu dalam aktivitas sehari-hari dalam sharing hal-hal kecil yang terjadi di sekitarnya bahkan dalam rupa olok-olok penuh canda dan tawa khas anak-anak SMA Kolese De Britto.

\section{Pendidikan yang Memerdekakan di SMA Taruna Nusantara}

Sistem Pendidikan di SMA Taruna Nusantara menganut sistem Among Ki Hadjar Dewantoro yang dalam kerangka pikirannya merupakan manifestasi dari perpaduan konsep pendidikan konservatif dan pendidikan modern (SMA Taruna Nusantara, 2012, pp.3436). Pendidikan konservatif memandang bahwa pendidikan adalah normatif. Oleh karena 
itu, lembaga pendidikan harus menetapkan kriteria dan norma-norma dasar kehidupan yang perlu dipahami, dihayati, dan dilaksanakan oleh siswa. Sedangkan dalam konsep pendidikan modern memandang setiap siswa merupakan individu yang unik. Anak terlahir dengan potensi masing-masing. Esensi tugas pendidikan adalah menumbuhkembangkan potensi yang dimiliki setiap siswa. Proses pendidikan harus mewadahi keanekaragaman potensi siswa tersebut.

Prosesnya penanaman nilai sebagai implementasi pendidikan konservatif dilakukan melalui tahap inisiasi (penanaman), drill (pengulangan), pembiasaan (habituasi). Dalam pelaksanaannya penanaman mulai dilakukan dengan "sistem among" dan cara "tutwuri handayani". Mengemong berarti memberikan kebebasan anak bergerak menurut kemauannya, tetapi pamong akan bertindak, kalau perlu dengan paksaan apabila keinginan anak akan membahayakan keselamatannya. Tutwuri handayani berarti pamong sebagai pemimpin mengikuti dari belakang, memberi kemerdekaan bergerak yang dipimpinnya, tetapi handayani, mempengaruhi dengan daya kekuatannya, kalau perlu dengan paksaan, apabila kebebasan yang diberikan itu dipergunakan untuk menyeleweng dan membahayakan diri.

Di samping dengan "sistem among" dan cara "tutwuri handayani" dalam rangka membekali nilai-nilai kepada siswa dilaksanakan dengan pendekatan kedisiplinan. Kedisiplinan yang berbasis kedisiplinan pribadi, yakni disiplin yang dilandasi tidak dengan keterpaksaan, melainkan karena kesadaran yang dilandasi oleh pengertian dan pemahaman yang benar. Kondisi tersebut benar-benar dilaksanakan di SMA Taruna Nusantara, bukan disiplin ketat model militer. Hasilnya disiplin menjadi kebutuhan sebagaimana orang membutuhkan makanan, bukan sebagai beban dan kewajiban yang memberatkan kehidupannya. Di SMA Taruna Nusantara kedisiplinan merupakan karakter yang akan dibentuk pada diri siswa sekaligus kedisiplinan merupakan metode untuk membangun karakter siswa termasuk karakter kebangsaannya. Hal ini tergambar pada Gambar 2.

Pembentukan karakter melalui penanaman (inisiasi), pembiasaan (drill) dan pembiasaan (habituasi) yang dilaksanakan dalam suasana kedisiplinan dengan Sistem
Among dan cara Tutwuri Handayani di SMA Taruna Nusantara, hasilnya sangat dirasakan. Para Pamong Pengajar Pengasuh, merasakan adanya perubahan perilaku antara anak kelas satu, dua dan tiga. Semakin tinggi kelas, akan tampak semakin menunjukkan perilaku disiplin. Beberapa Pamong Pengajar Pengasuh mengatakan bahwa mengajar kelas dua lebih enak dari pada mengajar anak kelas satu, bahkan lebih enak lagi mengajar kelas tiga. Indikator keberhasilan membangun karakter kedisiplinan siswa juga dapat dilihat dari semakin tinggi kelas siswa, semakin rendahnya frekuensi pelanggaran yang dilakukan siswa, juga semakin rendahnya hukuman yang diterima siswa. Karakter kebangsaan juga tumbuh seiring dengan meningkatnya kelas siswa. Untuk membangun kesadaran berbangsa dan bernegara dilaksanakan kegiatan upacara bendera secara rutin dan disiplin. Hasilnya siswa semakin meningkat rasa hormat pada simbolsimbol negara. Hal ini terlihat dari semakin tinggi kelas siswa, semakin meningkat kekhikmatnya dalam melaksanakan upacara bendera. Indikator lain siswa semakin peka terhadap tindakan penyimpangan pada bendera bangsanya. Misalnya: kesalahan pelipatan, kebalik pemasangan, pelecehan terhadap bendera, dan sebagainya. Prinsip Bhinneka Tunggal Ika benar-benar nampak dalam perilaku sehari-hari siswa.

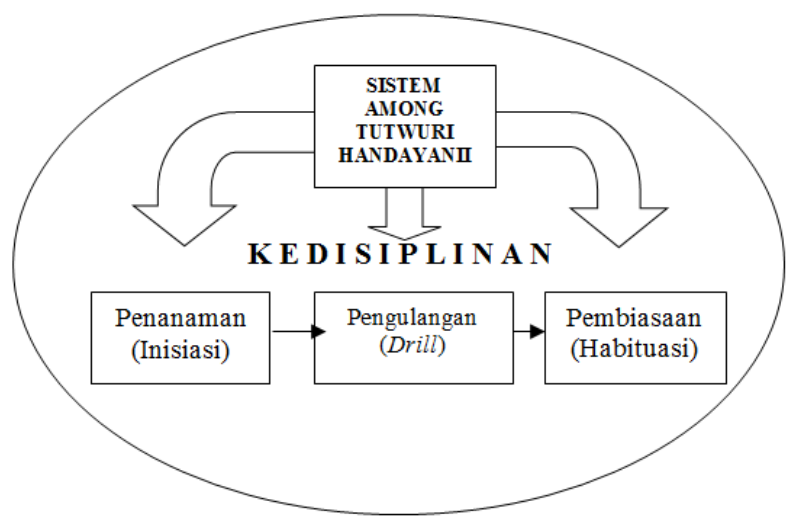

Gambar 2. Penanaman Kedisiplinan

\section{Hasil Sintesis Pola Pendidikan Nilai Kebangsaan Melalui Budaya Sekolah}

Penelitian ini menemukan bahwa melalui metode Paradigma Pedagogi Ignasian, "cura personalis" dan Pendidikan Bebas, SMA Kolese De Britto berhasil membangun karakter kebangsaan siswanya. Demikian halnya, SMA Taruna Nusantara dengan Sistem 
Among, Tutwuri Handayani dan kedisiplinan, berhasil membangun karakter kebangsaan siswanya. Bertolak dari keberhasilan tersebut peneliti berusaha membuat sintesis dari dua pola tersebut, guna memperoleh pola baru pendidikan nilai kebangsaan melalui budaya sekolah.

Penggabungan pola pendidikan bebas SMA Kolese De Britto dengan pola penanaman nilai melalui kedisiplinan SMA Taruna Nusantara tentunya merupakan perpaduan sinergis yang saling melengkapi dan saling mendukung pola pendidikan yang nampak saling bertentangan tersebut. Pendidikan nilai model kedisiplinan SMA Taruna Nusantara akan memberi kontribusi bekal nilai bagi terlaksananya pendidikan bebas bertanggung jawab yang diterapkan SMA Kolese De Britto, sehingga keputusan bebas yang diambil benar-benar bermutu, karena didasari hirarki nilai, norma dan suara hati yang tertanam dalam diri siswa. Di samping itu SMA Taruna Nusantara dapat juga mengambil model penanaman nilai pada siswa tidak sekedar memberikan pengalaman lapangan kepada siswa melalui berbagai kegiatan, tetapi secara utuh melengkapi dengan konteks, refleksi, aksi dan evaluasi sebagaimana dianjurkan dalam Paradigma Pedagogi Ignasian.

Cura personalis yang diterapkan di SMA Kolese De Britto akan lebih sempurna jika dilakukan selama 24 jam sebagaimana sistem among yang dilaksanakan di SMA Taruna Nusantara. Dengan perkataan lain sangat ideal jika SMA Kolese De Britto merubah diri menjadi sekolah berasrama, agar guru dan siswa dapat lebih intensif berinteraksi selama 24 jam. Hal ini berpeluang besar dilaksanakan karena sebagian besar siswa SMA Kolese De Britto adalah berasal dari luar DIY dan tinggal kost disekitar sekolah.

Jadi hasil sintesis pola pendidikan nilai kebangsaan melalui budaya sekolah adalah perlu dilakukan upaya memadukan antara konsep pendidikan konservatif dan konsep pendidikan modern. Penerapkan sistem pendidikan di satu sisi bertujuan untuk menanamkan (inisiasi) nilai-nilai normatif sebagai dasar pembentukan generasi muda dengan karakter yang kuat, di sisi lain juga memberikan peluang seluas-luasnya untuk tumbuh dan berkembangnya potensi dan kreativitas siswa. Dalam rangka membekali nilai-nilai kepada siswa termasuk nilai-nilai kebangsaan dilaksa- nakan dalam suasana kedisiplinan. Kedisiplinan yang dilandasi oleh disiplin pribadi, yakni disiplin yang dilandasi tidak dengan keterpaksaan, melainkan karena kesadaran yang dilandasi oleh pengertian dan pemahaman yang benar, sehingga disiplin menjadi kebutuhan, bukan sebagai beban dan kewajiban yang memberatkan kehidupannya.

Penanaman nilai juga perlu dilakukan melalui pendekatan cura personalis (pengenalan pribadi) dilaksanakan dengan Sistem Among dan Tutwuri Handayani selama 24 jam dalam arti perlu sekolah berasrama, agar interaksi guru dan siswa lebih intensif. Di samping itu untuk lebih mendarahdagingkan nilai-nilai termasuk nilai-nilai kebangsaan, dilaksanakan berbagai kegiatan penanaman, pengulangan dan pembiasaan dengan mengacu pada "Paradigma Pedagogi Ignasian" (Paradigma pedagogi Reflektif). Implementasi dari nilai-nilai yang telah tertanam, dipraktikkan melalui budaya pendidikan kebebasan yang bertanggungjawab, sehingga penanaman nilai kebangsaan tidak sekedar dalam ranah kognitif-afektif tetapi benar-benar sampai pada tataran perilaku kebangsaan siswa. Hal tersebut tercermin pada Gambar 3.

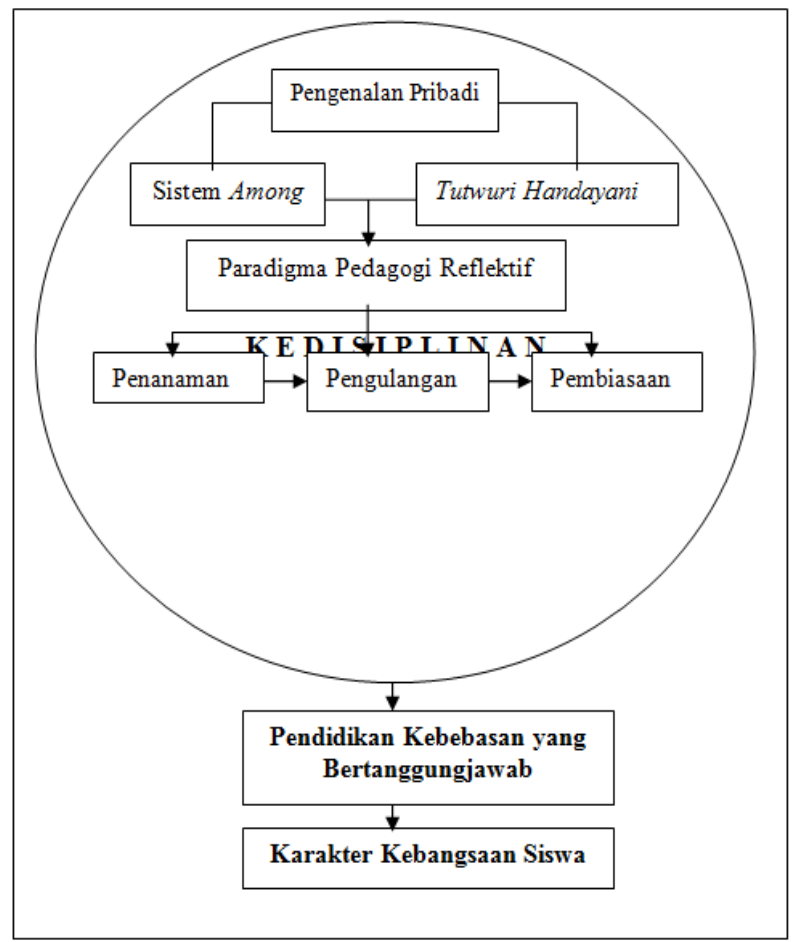

Gambar 3. Penanaman Nilai 


\section{SIMPULAN DAN SARAN}

\section{Simpulan}

Ada perbedaan dan persamaan antara SMA Kolese De Britto dengan SMA Taruna Nusantara, baik mengenai konsep bangunan kebangsaan yang akan ditanamkan pada siswa, pengembangan budaya sekolah yang mendukung pendidikan nilai kebangsaan, maupun pola pendidikan nilai kebangsaan melalui budaya sekolah. Meskipun demikian peneliti menemukan bahwa pendidikan nilai kebangsaan melalui budaya sekolah efektif menanamkan karakter kebangsaan siswa di kedua sekolah.

Hasil sintesisnya penggabungan budaya disiplin, cura personalis dan Paradigma Pedagogik Ignasian akan memaksimalkan penanaman nilai kebangsaan siswa tidak sekedar pada ranah kognitif tetapi sampai tataran perilaku kebangsaan, pada gilirannya nilainilai kebangsaan yang tertanam akan dijadikan acuan dalam pengambilan keputusan bebas yang bertanggung jawab.

\section{Saran}

Penelitian ini menemukan bahwa pendidikan nilai kebangsaan melalui budaya sekolah efektif untuk membangun karakter kebangsaan siswa. Oleh karena itu, perlu ada usaha serius menerapkan pola pendidikan nilai kebangsaan melalui budaya sekolah sebagai alternatif kegagalan Pendidikan Kewarganegaraan membangun kebangsaan sejati.

\section{DAFTAR PUSTAKA}

Gellner, E. (2008). Nations and nationalism. Ithaca: Cornell University Press.

Katalog Sekolah Menengah Atas Taruna Nusantara Magelang. (2012). Magelang: SMA Taruna Nusantara.

Miles, M.B. \& Huberman, A.M. (1992). Analisis data kualitatif (diterjemahkan oleh Tjetjep Rohendi Rohidi). Jakarta. UI Press.

Prough, E. (2008). That Was Then, This is Now: A Study of Socialization of High School Students. Diserta-si Doktor, Wayne State University, Detroit, Michi-gan.

Republik Indonesia. Permendikanas No 53 Tahun 2006 tentang Pengembangan Diri.

Sastrapratedja. (2001). Pendidikan sebagai humanisasi.Yogyakarta: Penerbit Universitas Sanata Dharma.

Wagiran. (2011). Developing technical vocational education and training (TVET) student character throught school culture. Makalah disajikan dalam Seminar Nasional IKA UNY di UNY.

Zuchdi, D. (2010). Humanisasi pendidikan. Menemukan kembali pendidikan yang manusiawi. Jakarta: PT.Bumi Aksara 